\title{
Guest Editorial: Celebrating the Two Year Anniversary and Announcing the Fifth Issue
}

With all the supports from international LIS community and the dedications of our editorial team, the International Journal of Librarianship has been proceeding steadily. At this point, IJoL has published 4 issues and 45 articles. Among them, there are 4 editorial reports, 21 featured articles, 3 reports from the field, 2 commentaries, 7 book reviews, 3 articles on LIS education around the world, and 5 news reports. These articles covered a wide variety of topics including information literacy, digital resource discovery, makerspace, digital stewardship, social science data services in both public and academic libraries in Canada, China, Finland, South Africa, UK, and USA.

Below is a quick run-down of the fifth issue:

\section{"Featured Articles" section}

Magliaro and Munro analyzed the information literacy needs and levels of 44 social work graduate students at a mid-sized Canadian university using the Technology Acceptance Model in their article titled "Study of the Information Literacy Needs of Social Work Graduate Students at a midsized Canadian university." The analysis from this study provides a more holistic presentation of social work graduate students' information literacy needs.

By telling the story of the Berlin State Library in the twentieth century in the article titled "From a Divided Library in a Divided City to One Library in Two Houses: A Centennial for a Great European Research Library Reunited and Restored," Daniel William Kinney discussed the impact of different historical eras on the library as a cultural institution and how the library is once again serving international scholarship and preserving an important part of the world's documentary heritage despite destruction of the building and the evacuation and loss of collections.

In their article, "Shared Next Generation ILSs and Academic Library Consortia: Trends, Opportunities and Challenges," Liu and Fu reported two case studies of the adoption of Shared Next Generation ILSs in academic library consortia. One library consortium of 39 academic libraries in Oregon, Washington, and Idaho has completed the migration. The significant impacts, numerous opportunities and challenges from the shared next generation ILS on its member libraries have been discussed. The other library consortium of 21 university libraries in Ontario, Canada is currently launching and implementing the new system.

In her article "New Developments of Chinese Government Publications and Library Collections," Xue discussed the scope of Chinese government publications, its availability in digital format, the types of publications libraries usually collect, and opportunities and challenges in collecting them.

Nero and He described the process and workflow of the quality control of cataloging tangible and 
electronic resources in their library; and also discussed why quality control on cataloging is performed. The importance of training cataloging staff on current cataloging rules and practices as a preventive measure to reduce mistakes is an essential part of the process. The ultimate goal of quality control is to eliminate errors and ensure the library's resources are accessible.

\section{Commentaries section}

In the paper titled "Vocabulary Integration Reexamined," Dr. Choi reexamined the issues and challenges in vocabulary mapping and integration between different controlled vocabulary systems. The paper outlined the history of the study of vocabulary mapping efforts and suggested a way in which the emerging practices on semantic issues and mapping problems can be articulated.

\section{Library Associations Around the World}

In his article "Promoting translational research within the global library and information community: access to research dissemination, promotion of timely issues, and professional development through IFLA Journal," Professor Witt, the Editor of IFLA Journal described how IFLA Journal seeks to help bridge the gap between research and practice in the global LIS profession through an editorial process and publishing mandate by encouraging mixed methods approaches to research, and engaging librarians and their communities in the research process.

\section{News section}

Michael Huang and IJoL Editor-in-Chief Guoying Liu reflected upon their conference experiences in the 9th Shanghai International Library Forum (SILF 2018). This international conference promotes international interaction and collaboration among LIS community.

Lastly, I would like to thank all the editors and peer reviewers who worked tirelessly on this issue. I would also like to extend my gratitude and thankfulness to all the content contributors for this issue.

Xiaoai Ren, Valdosta State University 